\title{
Autotaxin is an inflammatory mediator and therapeutic target in thyroid cancer
}

\section{Matthew G K Benesch, Yi M Ko', Xiaoyun Tang, Jay Dewald, Ana Lopez-Campistrous', Yuan Y Zhao' ${ }^{2}$, Raymond Lai ${ }^{3}$, Jonathan M Curtis ${ }^{2}$, David N Brindley and Todd P W McMullen'}

Signal Transduction Research Group, Department of Biochemistry, 357 Heritage Medical Research Centre, University of Alberta, Edmonton, Alberta, Canada T6G 2S2

${ }^{1}$ Department of Surgery, 2D4.41 WC Mackenzie Health Science Centre, University of Alberta, Edmonton, Alberta, Canada T6G 2R7

${ }^{2}$ Department of Agricultural, Food and Nutritional Science, University of Alberta, Edmonton, Alberta, Canada T6G 2P5

${ }^{3}$ Department of Laboratory Medicine and Pathology, University of Alberta, Edmonton, Alberta, Canada T6G 2R3
Correspondence should be addressed to T P W McMullen or D N Brindley

Emails

todd.mcmullen@ albertahealthservices.ca or david.brindley@ ualberta.ca

\begin{abstract}
Autotaxin is a secreted enzyme that converts extracellular lysophosphatidylcholine to lysophosphatidate (LPA). In cancers, LPA increases tumour growth, metastasis and chemoresistance by activating six G-protein coupled receptors. We examined $>200$ human thyroid biopsies. Autotaxin expression in metastatic deposits and primary carcinomas was four- to tenfold higher than in benign neoplasms or normal thyroid tissue. Autotaxin immunohistochemical staining was also increased in benign neoplasms with leukocytic infiltrations. Malignant tumours were distinguished from benign tumours by high tumour autotaxin, LPA levels and inflammatory mediators including IL1 $\beta$, IL6, IL8, GMCSF, TNF $\alpha$, CCL2, CXCL10 and platelet-derived growth factor (PDGF)-AA. We determined the mechanistic explanation for these results and revealed a vicious regulatory cycle in which LPA increased the secretion of 16 inflammatory modulators in papillary thyroid cancer cultures. Conversely, treating cancer cells with ten inflammatory cytokines and chemokines or PDGF-AA and PDGF-BB increased autotaxin secretion. We confirmed that this autotaxin/inflammatory cycle occurs in two SCID mouse models of papillary thyroid cancer by blocking LPA signalling using the autotaxin inhibitor ONO-8430506. This decreased the levels of 16 inflammatory mediators in the tumours and was accompanied by a $50-60 \%$ decrease in tumour volume. This resulted from a decreased mitotic index for the cancer cells and decreased levels of vascular endothelial growth factor and angiogenesis in the tumours. Our results demonstrate that the autotaxin/inflammatory cycle is a focal point for driving malignant thyroid tumour progression and possibly treatment resistance. Inhibiting autotaxin activity provides an effective and novel strategy for decreasing the inflammatory phenotype in thyroid carcinomas, which should complement other treatment modalities.
\end{abstract}

Endocrine-Related Cancer (2015) 22, 593-607
(C) 2015 Society for Endocrinology Printed in Great Britain
Published by Bioscientifica Ltd 


\section{Introduction}

Worldwide, the incidence of papillary thyroid cancer has doubled in the past decade and is expected to overtake colorectal cancer as the fourth leading cancer diagnosis by 2030 (Pellegriti et al. 2013, Jung et al. 2014, Rahib et al. 2014). Although overall survival rates are excellent, thyroid cancer has a very high propensity to metastasize, and between 25 and $40 \%$ of patients require either surgery and/or radioactive iodine to control the disease (Hughes et al. 2012, Jung et al. 2014). Of this group $\sim 20 \%$ demonstrate metastatic disease that is resistant to radioactive iodine (Hughes et al. 2012, Jung et al. 2014). These patients suffer a disproportionate burden because they are often subject to repeated attempts at surgical extirpation of metastatic disease as well as repeat, high-dose application of radioactive iodine (Hughes et al. 2012). The introduction of tyrosine receptor kinase inhibitors in clinical trials has generated mixed results with response rates between 15 and 50\%, and few patients derive a lasting benefit from these adjuvant treatments (Anderson et al. 2013). Moreover, there are no clinically utilized markers for metastatic disease, and morphologic predictors of papillary thyroid cancer behaviour are imperfect. Although new molecular diagnostics based on the presence of RET/PTC, $R A S, B R A F$, and other mutations may aid clinicians in identifying malignant nodules, treatment plans rely primarily on morphologic characteristics such as tumour size. At present, personalized therapy remains out of reach (Anderson et al. 2013). Predicting occurrence of radioactive-iodine resistant and recurrent disease requires a better understanding of the pathways that drive thyroid tumour growth and metastases.

Aggressive malignancy is driven by a migratory phenotype that shares common pathways with inflammation (Colotta et al. 2009, Mantovani 2010). We propose that autotaxin, and its production of lysophosphatidate (LPA), is an important component of this inflammatory axis (Benesch et al. 2014a). LPA drives cancer cell division, survival and migration by activation of six G-protein coupled receptors (Brindley et al. 2013, Benesch et al. 2014a). The autotaxin gene is among the top 40 upregulated genes in metastatic colon, breast and prostate cancers (Euer et al. 2002). LPA contributes significantly to the resistance of effective cancer therapy (Brindley et al. 2013). LPA protects cancer cells from radiation-induced cell death by depleting cells of siva-1, a pro-apoptotic signalling protein, and by stimulating pro-survival kinase pathways (Brindley et al. 2013). LPA also decreases the efficacy of chemotherapy by increasing the expression of antioxidant genes and multi-drug resistant transporters (Venkatraman et al. 2015).

Autotaxin is normally produced in response to injury and inflammation and its levels fall with the resolution of tissue repair (Benesch et al. 2014a, 2015). Uncontrolled inflammation disrupts the healing cycle and high autotaxin levels lead to a variety of pathological conditions such as arthritis and inflammatory bowel disease (Nikitopoulou et al. 2012, Hozumi et al. 2013, Benesch et al. 2014a). Moreover, persistently high autotaxin levels are linked to tumorigenesis and tumour progression in animal models of breast cancer, melanoma and glioblastoma (Jonkers \& Moolenaar 2009, Altman et al. 2010, Bhave et al. 2013, Benesch et al. 2014b, Venkatraman et al. 2015). Cancers have been described as 'wounds that do not heal' (Dvorak 1986, Schafer \& Werner 2008, Hanahan \& Weinberg 2011), and inflammation is a hallmark of cancer progression (Allavena et al. 2008, Germano et al. 2008, Wu et al. 2010, Chopra et al. 2013, Grivennikov 2013). The role of individual cytokines such as IL1 $\alpha$, IL6 and IL17 has been documented in the growth of solid tumours such as pancreatic, gastric and colorectal cancers (Tjomsland et al. 2013, Wang et al. 2014, Li et al. 2015). Despite an increasing appreciation for the role of inflammation in thyroid cancer progression, the connection between particular inflammatory signals and the potential for locally aggressive and metastatic papillary thyroid cancer variants is poorly understood (Cunha et al. 2014a,b, Ehlers \& Schott 2014, Marcello et al. 2014, Provatopoulou et al. 2014, Tafani et al. 2014, Ward 2014).

In the present study we examined $>200$ human thyroid biopsies and demonstrated that malignant tumours are distinguished from benign tumours and normal thyroid tissue by high autotaxin activity and LPA concentrations coupled with a four- to tenfold increase in inflammatory chemokine and cytokine levels. The only exception to this was that samples from patients with thyroiditis in the absence of cancer also had high autotaxin expression. We established the mechanistic explanation for these results by demonstrating that autotaxin-mediated LPA formation is a central component of a vicious cycle of inflammatory chemokine and cytokine production, which stimulates further autotaxin secretion. Ten of the inflammatory mediators that we tested, and platelet-derived growth factor (PDGF), markedly increased autotaxin secretion by thyroid cancer cells. LPA in turn increased the secretion of 14 inflammatory chemokines and cytokines, PDGF and vascular endothelial

Published by Bioscientifica Ltd. 
growth factor (VEGF). The relevance of these findings was demonstrated in vivo. Inhibition of autotaxin activity disrupted the cycle of inflammation in two mouse models of papillary thyroid cancer consequently decreasing tumour growth, proliferative index and angiogenesis. Our work provides a novel demonstration that blocking autotaxin activity provides a unique strategy for decreasing inflammatory chemokine and cytokine expression, thyroid cancer cell growth and tumour angiogenesis.

\section{Materials and methods}

\section{Patient specimens and cell culture}

Patient consent, tissue isolation and banking protocols were assessed and approved by the Alberta Research Tumour Bank and the Northern Alberta Research Ethics Board Pro00018758. All of the patients with papillary thyroid cancer who were identified on initial fine needle aspiration cytology and ultimately confirmed histologically on the final pathologic specimens were included. Patients with other concurrent malignancies, anaplastic or other poorly differentiated follicular carcinomas of the thyroid and previous radiation exposure were excluded. Two pathologists confirmed the diagnosis on core sections and validated all of the histologic specimens prepared for the tissue arrays. Specimens prepared for primary culture or tissue banking were placed in culture medium or optimal cutting temperature compound or were flash frozen, respectively, within $10 \mathrm{~min}$ of devascularization. A representative frozen section determination was used to ensure that $>90 \%$ of the banked specimens represented the thyroid neoplasm, benign or malignant, or histologically normal thyroid tissue. Benign specimens with leukocytic infiltrations were excluded. Primary culture specimens were prepared and purified using the Cancer Cell Isolation kit (CI0010, Affymetrix, Santa Clara, CA, USA) according to its protocol. Cells were cultured in highglucose DMEM containing 10\% fetal bovine serum (FBS), $1 \%$ penicillin/streptomycin $(\mathrm{P} / \mathrm{S}), 10 \mathrm{mU} / \mathrm{ml}$ thyroid stimulation hormone, $10 \mu \mathrm{g} / \mathrm{ml}$ insulin, $5 \mu \mathrm{g} / \mathrm{ml}$ transferrin, $10 \mathrm{nM}$ hydrocortisone, $10 \mathrm{ng} / \mathrm{ml}$ somatostatin and $10 \mathrm{ng} / \mathrm{ml}$ glycyl-L-histidyl-L-lysine acetate (AmbesiImpiombato et al. 1980) and incubated at $37^{\circ} \mathrm{C}, 5 \% \mathrm{CO}_{2}$ and $95 \%$ humidity. Experiments were performed within 3-4 passage numbers of isolation and purification. 8305C (ACC-133) thyroid cancer cells were obtained from DSMZ (Braunschweig, Germany), and SW-579 (HTB-107) thyroid cancer cells were obtained from American Type Culture Collection (ATCC, Manassas, VA, USA), where cell lines were authenticated by short tandem repeat analysis. All of the experiments were performed on cells 3-8 passage numbers from the time they were received. Cell lines were proven to be mycoplasma free using the MycoAlert Mycoplasma Detection kit (Lonza, Allendale, NJ, USA). Low passage number cells were cultured in RPMI 1640 media with $10 \%$ FBS and $1 \% \mathrm{P} / \mathrm{S}$.

\section{Mouse studies}

Animal procedures were conducted in accordance with the Canadian Council of Animal Care as approved by the University of Alberta Welfare Committee. Eight- to 10-week-old female Fox Chase-SCID beige (CB17.CgPrkdc $\left.c^{\text {scid }} L y s t^{b g-J} / \mathrm{Crl}\right)$ mice (18-20 g) were obtained from Charles River (Kingston, ON, Canada). Mice were maintained at $21 \pm 2{ }^{\circ} \mathrm{C}, 55 \pm 5 \%$ humidity and a standard $12 \mathrm{~h}$ light: $12 \mathrm{~h}$ darkness cycle with free access to food and water. $5 \times 10^{5} 8305 \mathrm{C}$ or $1 \times 10^{6} \mathrm{SW}-579$ cells were prepared (Benesch et al. 2014b) and injected subcutaneously into the flank with a 27-gauge needle while mice were anesthetized with $5 \%$ isoflurane. Tumours became palpable after 7 days when mice were gavaged daily with water or $20 \mathrm{mg} / \mathrm{kg}$ ONO-8430506 (Ono Pharmaceuticals, Osaka, Japan; patent WO2012005227) (Benesch et al. 2014b, Saga et al. 2014, Venkatraman et al. 2015) and tumour volume was measured (Benesch et al. 2014b).

\section{Immunohistochemistry}

Immunohistochemistry was performed on formalin-fixed, $5 \mu \mathrm{m}$ paraffin-embedded tissue sections (Zhang et al. 2012, Benesch et al. 2014b) using the Dako LSA+Universal kit (K0679) and staining was visualized using Dako Envision + rabbit HRP (K4002) (Burlington, ON, Canada). A rabbit IgG isotype control (bs-0295P, Bioss Antibodies; Woburn, MA, USA) was used as the control for staining. Tissue arrays were incubated with anti-autotaxin rabbit antibody (1:1000 dilution; ATX-102) from Dr Tim Clair (NCI, Bethesda, MA, USA) (Murata et al. 1994). Two independent pathologists reviewed and quantified the level of antibody staining from 0 (minimal), $1+, 2+$, to $3+$ (strong) without knowledge of the clinical outcome of the patients. At least two of the three tissue array cores needed to be intact for analysis and cores that were fragmented or incomplete were not scored. Autotaxin staining was assessed for each case, in triplicate. For xenograft tumours, staining was performed with anti-Ki67 (1:200 dilution; D3B5) rabbit antibody from Cell Signaling (Danvers, MA, USA) and anti-CD-31 rabbit antibody

Published by Bioscientifica Ltd. 
Table 1 Patient demographics of immunohistochemistry specimens

\begin{tabular}{|c|c|c|}
\hline & Normal $(n=33)$ & Benign neoplasm $(n=64)$ \\
\hline Mean age & $49.4 \pm 13.4$ & $51.9 \pm 13.7$ \\
\hline Female $(\%)$ & 85 & 59 \\
\hline Mean tumor size $(\mathrm{cm})$ & - & $3.6 \pm 1.9$ \\
\hline
\end{tabular}

\begin{tabular}{c} 
PTC $(\mathbf{L N}-)(n=123)$ \\
\hline $48.6 \pm 15.3$ \\
72 \\
$2.3 \pm 1.8$
\end{tabular}

\begin{tabular}{c} 
PTC $(\mathbf{L N}+)(n=71)$ \\
\hline $46.9 \pm 16.6$ \\
70 \\
$2.6 \pm 1.5$
\end{tabular}

$\frac{\text { LN }(n=15)}{51.2 \pm 18.3}$
73
$4.1 \pm 1.6$

PTC, papillary thyroid cancer; LN, metastatic lymph node status. Results shown are means \pm S.D.

(1:50 dilution; ab28364) from Abcam (Toronto, ON, Canada) and quantified from at least three random fields per specimen. Images were acquired at $10 \times$ and $40 \times$ using a Zeiss Axioskop 2 imaging system (Carl Zeiss Canada, Toronto, ON, Canada).

\section{Mutliplex measurements}

Eve Technologies Corp. (Calgary, AB, Canada) analysed 64 human cytokines, chemokines and growth factors. This analysis used a MILLIPLEX Human Cytokine/Chemokine 41-plex kit and a MILLIPLEX Human Cytokine/Chemokine 23-plex kit (Millipore, St Charles, MO, USA), according to the manufacturer's protocol on a Luminex 100 system (Luminex, Austin, TX, USA) (Supplementary Table 1, see section on supplementary data given at the end of this article for a list of analytes). Tissue specimens (5-10 mg) were homogenized in $200 \mu \mathrm{l}$ of $20 \mathrm{mM}$ Tris $\mathrm{HCl}(\mathrm{pH} 7.5)$ buffer with $0.5 \%$ Tween $20,150 \mathrm{mM} \mathrm{NaCl}$ and protease inhibitor, centrifuged for $10 \mathrm{~min}$ at $4{ }^{\circ} \mathrm{C}$ and then the supernatant was transferred to a fresh tube. Protein content was measured using the BCA protein assay (Thermo Fisher Scientific, Rockford, IL, USA) and adjusted to $5 \mu \mathrm{g} / \mu \mathrm{l}$. For supernatant analysis, cancer cells were seeded in 12-well plates, grown to $\sim 70 \%$ confluence and then washed and pre-incubated for $6 \mathrm{~h}$ in $1 \mathrm{ml}$ phenol red-free RPMI 1640 medium containing delipidated FBS (FBSC) that was treated with 1\% charcoal to remove lipids (Gaetano et al.
2009, Samadi et al. 2009). The media were then changed with or without an addition of $5 \mu \mathrm{M}$ oleoyl-LPA and incubated for $24 \mathrm{~h}$. Conditioned media were centrifuged prior to multiplex analysis. Measurements were normalized to both volume of medium and cell protein.

\section{Real-time quantitative RT-PCR}

RNA was isolated from Trizol (Invitrogen Life Technologies) using the Direct-zol RNA MiniPrep kit (R2052; Zymo Research, Irvine, CA, USA) according to the manufacturer's instructions. RT and quantitative RT-PCR (qRT-PCR) was then performed (Gaetano et al. 2009). Gene expression was normalized to glyceraldehyde phosphate dehydrogenase (GAPDH) and essentially the same results were obtained relative to cyclophilin A. All primers are from Integrated DNA Technologies (Coralville, IA, USA) and used at a final concentration of $250 \mathrm{nM}$ : CSF2: F: 5'-ATGATGGCCAGCCACTACAA-3', R: 5'-CTGGCTCCCAGCAGTCAAAG-3'; CXCL10: F: 5'-AGCAGAGGAACCTCCAGTCT-3', R: 5'-ATGCAGGTACAGCGTACAGT-3'; ENPP2 (autotaxin): F: 5'-CATTTATTGGTGGAACGCAGA-3', R: 5'-ACTTTGTCAAGCTCATTTCC-3'; GAPDH: F: 5'-ACTTTGTCAAGCTCATTTCC-3'， R: 5'-TCTTACTCCTTGGAGGCCAT-3'; IL1A: F: 5'-CTTCTGGGAAACTCACGGCA-3', R: 5'-AGCACACCCAGTAGTCTTGC-3', IL1B: F: 5'-AACAGGCTGCTCTGGGATTC-3', R: 5'-AGTCATCCTCATTGCCACTGT-3'; IL6: F: 5'-AGTTCCTGCAGAAAAAGGCAAAG-3',

Table 2 Percentage (\%) of specimens staining for autotaxin. Results are shown for normal thyroid, benign neoplastic tumours, papillary thyroid cancer primary tumours with and without metastases and papillary thyroid cancer metastases in lymph node deposits. Benign neoplastic tumours were further subdivided into patients with Hashimoto's thyroiditis or otherwise significant lymphocytic infiltration as defined on the final pathological report

\section{Scoring}

Normal thyroid* $(n=33)$

Benign neoplastic tumours ${ }^{\dagger}(n=64)$

No lymphocytic infiltration ${ }^{\ddagger}(n=41)$

Lymphocytic infiltration $^{\ddagger}(n=23)$

Node-negative primary tumours ${ }^{*}{ }^{\dagger}(n=123)$

Node-positive primary tumours ${ }^{*}{ }^{\dagger}(n=71)$

Lymph node metastasis*, ${ }^{\dagger}(n=15)$

${ }^{\star} P<0.0001 ;{ }^{\dagger} P<0.0001 ;{ }^{\ddagger} P<0.005$.

\begin{tabular}{c}
\hline 0 (\%) \\
\hline 81 \\
26 \\
24 \\
4 \\
8 \\
8 \\
13
\end{tabular}

\begin{tabular}{c}
\hline $1+(\%)$ \\
\hline 8 \\
34 \\
34 \\
13 \\
9 \\
8 \\
27 \\
\hline
\end{tabular}

\begin{tabular}{c}
\hline $\mathbf{2}+(\%)$ \\
\hline 11 \\
20 \\
24 \\
17 \\
30 \\
31 \\
40
\end{tabular}

\begin{tabular}{c}
$3+(\%)$ \\
\hline 0 \\
18 \\
17 \\
65 \\
52 \\
53 \\
20
\end{tabular}


R: 5'-AAAGCTGCGCAGAATGAGATG-3'; IL8: F: 5'-CCACCGGAAGGAACCATCTC-3', R: 5'-CTCCTTGGCAAAACTGCACC-3'; PDGFA: F: 5'-AAGCAGCCAACCAGATGTGA-3', R: 5'-GGAGGAGAACAAAGACCGCA-3'; PDGFB: F: 5'-CTTCCTGTCTCTCTGCTGCTA-3', R: 5'-CATCTTCCTCTCCGGGGTC-3'; TNFA: F: 5'-CCC ATGTTGTAGCAAACCCTC3', R: 5'-CCCATGTTGTAGCAAACCCTC-3'.

\section{Measurement of lysophospholipid concentrations}

Tissue specimens and plasma were extracted and quantified by mass spectrometry (Benesch et al. 2014b).

\section{Measurement of autotaxin activity}

Conditioned media (phenol red-free RPMI 1640, 1\% FBSC) were prepared by incubating cells at $\sim 70 \%$ confluency in six-well plates with $2 \mathrm{ml}$ medium for $48 \mathrm{~h}$ following a 6-h preincubation with $1 \%$ FBSC. Control medium was not exposed to cells. Collected conditioned media were centrifuged and concentrated $\sim 25$-fold using an Amicon Ultra-0.5 Centrifugal Filter Unit with Ultracel-10 membrane (UFC501096) (EMD Millipore, Billerica, MA, USA). Autotaxin activity was measured by the FS-3 assay (Gaetano et al. 2009, Benesch et al. 2015) by mixing $20 \mu \mathrm{l}$
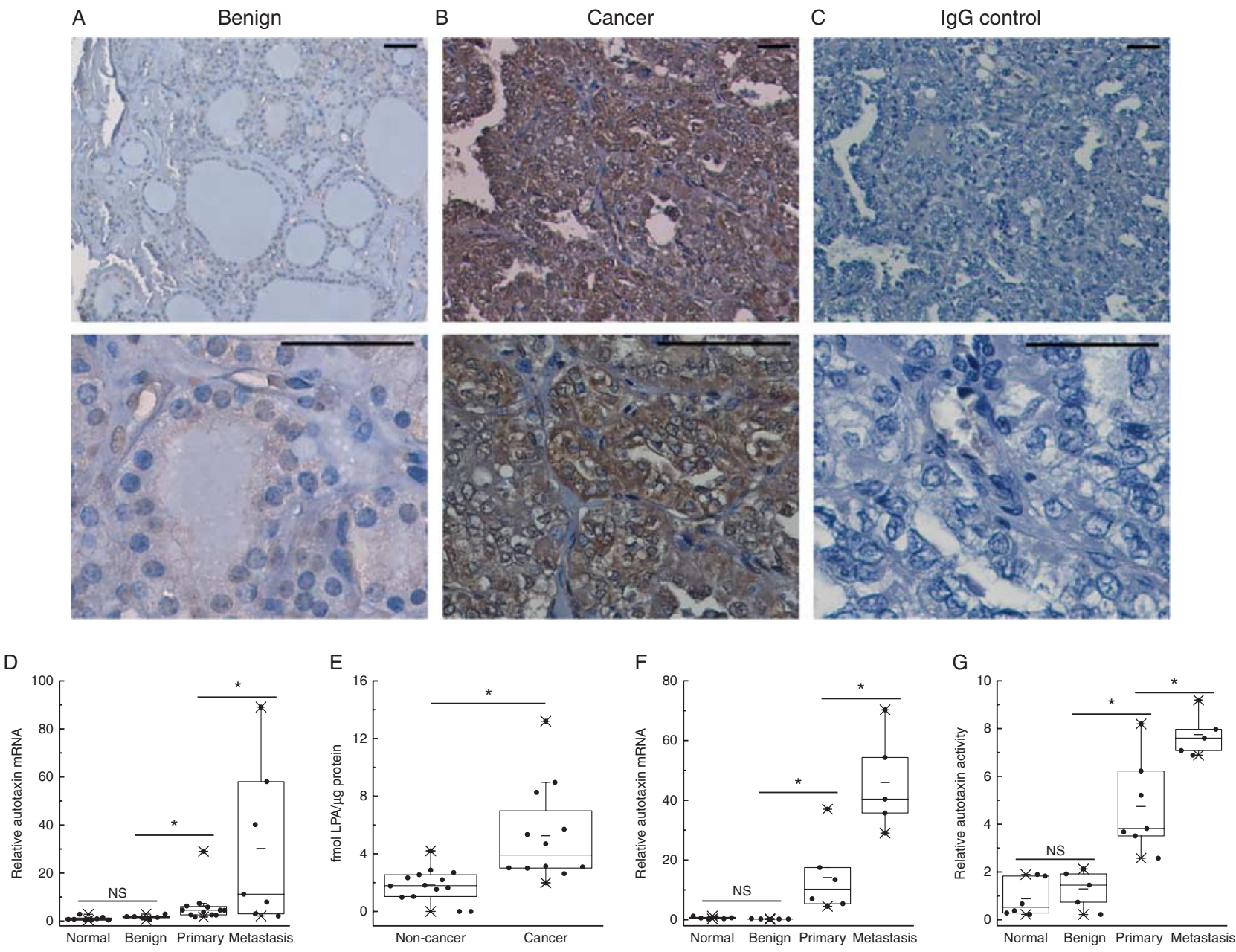

\section{Figure 1}

Autotaxin is highly expressed in papillary thyroid cancer but not in benign specimens. Representative immunohistochemical stains of autotaxin at low power (10 $\times$; top) and high power (40 $\times$; bottom) are illustrated in (A) benign thyroid adenomas $(n=64)$, (B) primary tumours $(n=152)$ and (C) rabbit IgG isotype control on primary tumours. (D) Autotaxin mRNA measurements in patient samples normalized to GAPDH. $n=7-12$ per group. (E) Non-cancer specimens (normal or benign nodules) have lower LPA levels than cancer (primary or metastasis) specimens (sum of LPA species

C16:0, C18:0, C18:1 and C20:4, normalized to total extracted protein) $n=12-14$ per group. (F) Autotaxin mRNA measurements and (G) activity measurements in conditioned media from primary cultures established from patient tissues $n=5-7$ per group. Box plots show minimum, mean and maximum values $(-), 25$ th, 50th and 75 th percentiles (box) and 1st and 99th percentiles $(\mathrm{x}) .{ }^{*} P<0.05$ by ANOVA with post hoc test; NS, not significant. A full colour version of this figure is available at http://dx.doi.org/10.1530/ ERC-15-0045.

Published by Bioscientifica Ltd. 

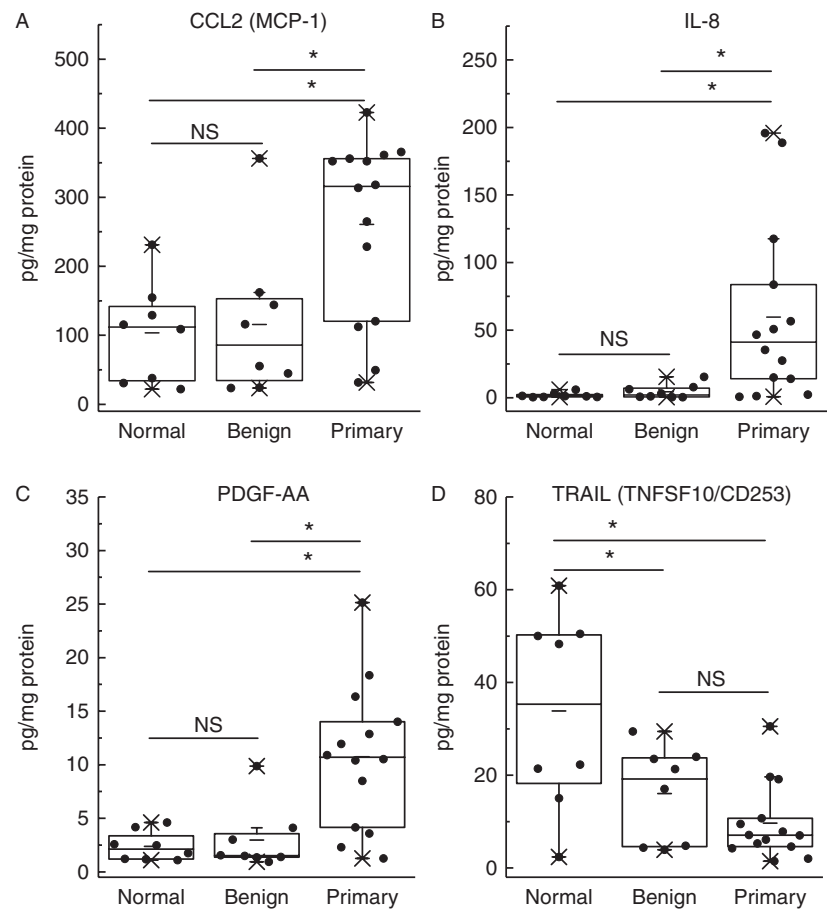

Figure 2

(A) Chemokines, (B) cytokines and (C) growth factors are significantly elevated in patient primary thyroid cancer specimens compared to benign nodules and normal thyroid tissue. (D) TRAIL, a driver of apoptosis, is deceased in primary tumors. Multiplex measurement results are normalized to total protein content. Box plots show minimum, mean and maximum values $(-), 25$ th, 50th, and 75 th percentiles (box) and 1st and 99th percentiles (x). $n=8-14$ specimens per group; ${ }^{*}<0.05$ by ANOVA with post hoc test. NS, not significant. Results for additional inflammatory mediators are presented in Supplementary Figure 3.

of concentrated conditioned medium with $70 \mu \mathrm{l}$ of $3 \mu \mathrm{M}$ FS-3 substrate, and fluorescence intensity was normalized to cell protein content. All of the agonists used to induce autotaxin expression were purchased from Peprotech (Rocky Hill, NJ, USA). Autotaxin activity was measured in mouse plasma by the choline released from $3 \mathrm{mM}$ C14:0-lysophosphatidylcholine (LPC) (Benesch et al. 2014b).

\section{Statistics}

Results are means \pm s.E.M. Two-tailed Student's $t$-test, a paired $t$-test and one-way ANOVA with a Bonferonni post hoc test were used to test significance as appropriate. Statistics were calculated and results plotted using Origin Pro 9.1 (OriginLab Corporation, Northampton, MA, USA). Correlations for staining were assessed using Fisher's exact test for tables and the Spearman rank correlation for continuous variables.

\section{Results}

Expression of autotaxin and inflammatory chemokines, cytokines and growth factors is characteristic of malignant thyroid tumours and metastases

Table 1 summarizes the demographic results for tissue arrays comprising thyroid cancer patients with and without metastases. We determined autotaxin expression in primary tumour specimens with $(n=71)$ and without $(n=123)$ nodal metastases as well as in nodal metastatic sections $(n=15)$, benign follicular adenomas $(n=64)$ and
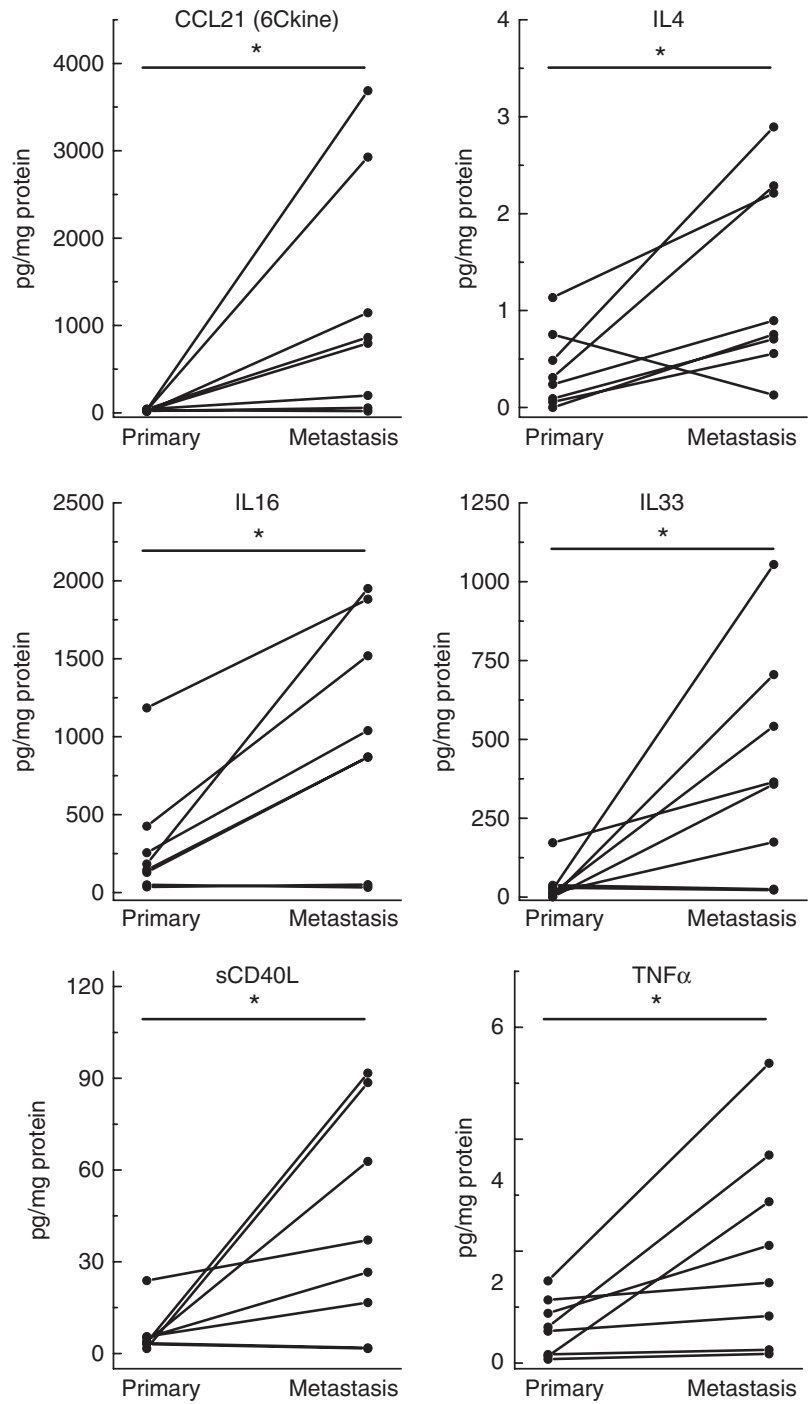

Figure 3

Chemokines and cytokines are significantly elevated in patient-matched thyroid metastatic lymph node nodules (metastasis) compared to primary thyroid tumours (primary). Multiplex measurement results are normalized to total protein content. $n=8$ matched specimens, $* P<0.05$ by paired $t$-test.

Published by Bioscientifica Ltd. 

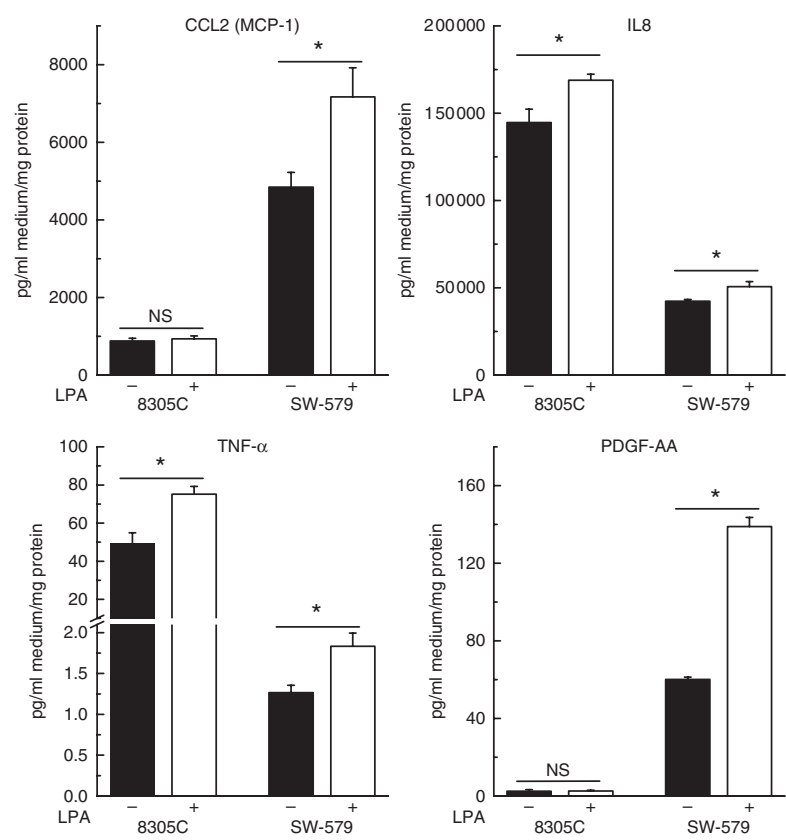

Figure 4

Chemokine, cytokine and growth factor secretion in 8305 C and SW-579 thyroid cancer cells is significantly increased by LPA treatment. $8305 \mathrm{C}$ and SW- 579 cancer cells were treated with $5 \mu \mathrm{M}$ LPA for $24 \mathrm{~h}$ in $1 \%$ FBSC medium and medium was analysed by multiplex measurements. Results are normalized to both total volume of medium and cell protein content. Results are means \pm S.E.M. from four independent experiments, $* P<0.05$ compared to no treatment; NS, not significant. Results for additional inflammatory mediators are presented in Supplementary Figure 4.

neighbouring normal thyroid tissue $(n=33)$ (Table 2). In accordance with clinical standards, patients in this cohort with biopsy-proven papillary thyroid cancer had ipsilateral or bilateral level 6 lymph node dissections to address the possibility of lymphatic metastases. Autotaxin staining was typically cytoplasmic/extracellular (Fig. 1A, B and C). Autotaxin protein expression was undetectable, or minimally so, in about $90 \%$ of the non-neoplastic thyroid tissue. In benign neoplastic tissue comprising follicular adenomas, autotaxin expression was typically low, but a small fraction did stain positive for autotaxin (Table 2). On further analysis, autotaxin staining in benign neoplasms correlated strongly with diffuse lymphocytic infiltration or Hashimoto's thyroiditis $(P<0.005)$ (Table 2$)$. More than $80 \%$ of the primary papillary thyroid tumours exhibited strong autotaxin staining regardless of age, gender, tumour size, nodal status and multifocality. There was no correlation between BRAF status, when known, and autotaxin staining (not shown). Primary tumours were much more likely to demonstrate moderate or strong staining compared to normal thyroid tissue $(P<0.001)$ or benign neoplasms $(P<0.001)$ (Table 2$)$. Nodal metastases also showed stronger autotaxin staining compared to normal thyroid tissue and benign thyroid neoplasms $(P<0.001)$ (Table 2). mRNA levels obtained from snap frozen specimens further outlined the strong preference for autotaxin expression in malignancy, consistent with previous reports (Barden et al. 2003, Kehlen et al. 2004, Seifert et al. 2008, Hassan et al. 2013). Primary papillary thyroid tumours and, even more so, lymph node metastases exhibited mRNA levels between three- and 30-fold higher than normal thyroid tissue or benign tumours (Fig. 1D) $(P<0.05)$. Increased autotaxin mRNA expression in primary tumours compared to normal tissue was confirmed in matching specimens from individual patients, and this increase was even greater in metastatic samples compared to matched primary tumours $(P<0.05)$ (Supplementary Figure 1, see section on supplementary data given at the end of this article). High autotaxin expression in thyroid tumours also correlated with greater
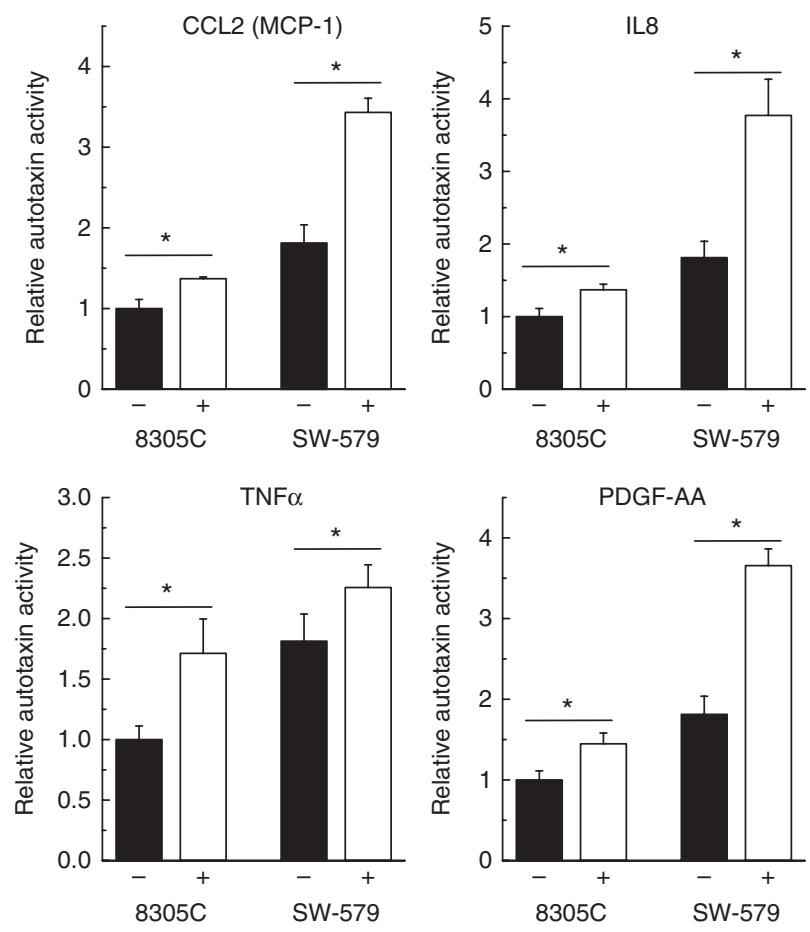

\section{Figure 5}

Chemokines, cytokines and growth factors increase autotaxin secretion from thyroid cancer cells. $8305 \mathrm{C}$ and SW-579 cancer cells were treated with $10 \mathrm{ng} / \mathrm{ml}$ CCL2 (MCP-1), IL8 or TNF $\alpha$, or $50 \mathrm{ng} / \mathrm{ml} \mathrm{PDGF-AA} \mathrm{for} 48 \mathrm{~h}$ in $1 \%$ FBSC. Autotaxin activity in concentrated conditioned medium was normalized to cell protein content. Results are from at least three independent experiments. ${ }^{*} P<0.05$ compared to no treatment. Results for additional inflammatory mediators are presented in Supplementary Figure 6.

Published by Bioscientifica Ltd. 
than twofold increases in LPA concentrations compared to the patients without thyroid cancer $(P<0.01)$ (Fig. $1 \mathrm{E}$, Supplementary Figure 2).

To quantify the levels of autotaxin production and to exclude other sources of production, we determined autotaxin expression in purified cells cultured from freshly isolated human tumours. The expression of autotaxin mRNA was tenfold higher in cancer cells from primary tumours and 40-fold higher in cells from metastatic nodules compared to cells from normal or benign thyroid samples (Fig. 1F). Furthermore, significantly higher levels of secreted autotaxin activity (Fig. 1G) were obtained in metastatic specimens compared to primary tumours $(P<0.01)$, benign tumours $(P<0.01)$ or normal thyroid tissue $(P<0.01)$. These results correlated closely with mRNA concentrations identified in corresponding tissues and define a clear role for autotaxin in primary and metastatic papillary thyroid cancer.

We also characterized 64 analytes encompassing regulators of communication between cells and their extracellular environment (chemokines, chemokines, lymphokines, interferons, colony stimulating factors and growth factors) in the human thyroid tissue isolates to define the inflammatory phenotype (Supplementary Table 1 for list of analytes and abbreviations); 15 of these were significantly higher in the papillary thyroid cancer tumours than in normal thyroid tissue or benign disease (Fig. 2, Supplementary Figure 3, see section on supplementary data given at the end of this article). None of these mediators were increased in benign neoplasms (without lymphocytic infiltrations) compared to normal tissue. In the primary tumours, we observed increases in inflammatory chemokines (CCL family and CXCL1) and a marked elevation of cytokines (Fig. 2, Supplementary Figure 3) involved with immune cell activation and migration (Turner et al. 2014). PDGF-AA levels are higher in malignancy (Fig. 2C) indicating probable activation of the PDGFR $\alpha$ cascade and its signalling pathways that are strongly associated with cell migration and angiogenesis as shown for papillary thyroid cancer (Xue et al. 2012, Zhang et al. 2012). Conversely, the level of TRAIL ligand (CD253), a central driver of apoptosis (Oikonomou \& Pintzas 2013), was decreased by $75 \%$ in primary tumours compared to normal tissue (Fig. 2D). The levels of all analytes are given in Supplementary Table 2. The metastatic phenotype was emphasized further by elevation of immune cell recruiters and modulators, CCL21, TNF $\alpha$, sCD40L, IL4, IL16 and IL33 in metastatic specimens matched with primary tumours (Fig. 3). The complete list of inflammatory modulators and the levels identified in primary tumour tissue and patient-matched metastatic deposits of papillary thyroid cancer is shown in Supplementary Table 3.
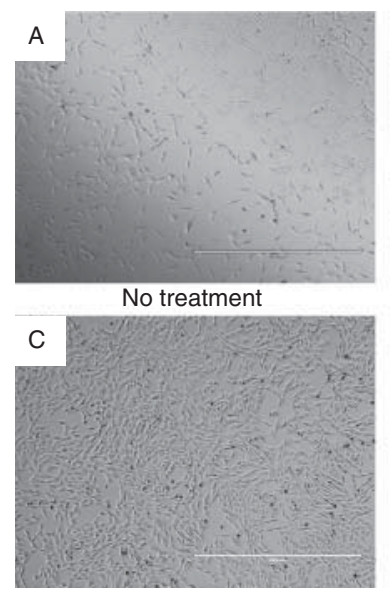

LPC

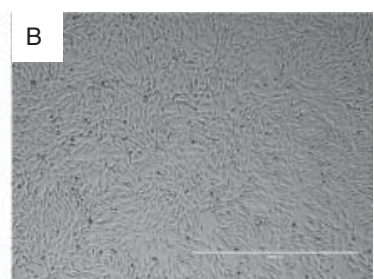

LPA

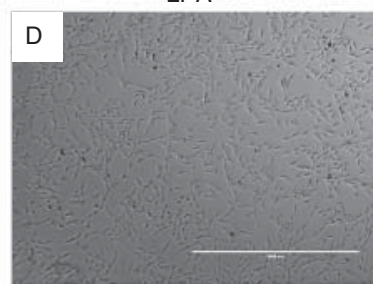

LPC + ONO-8430506

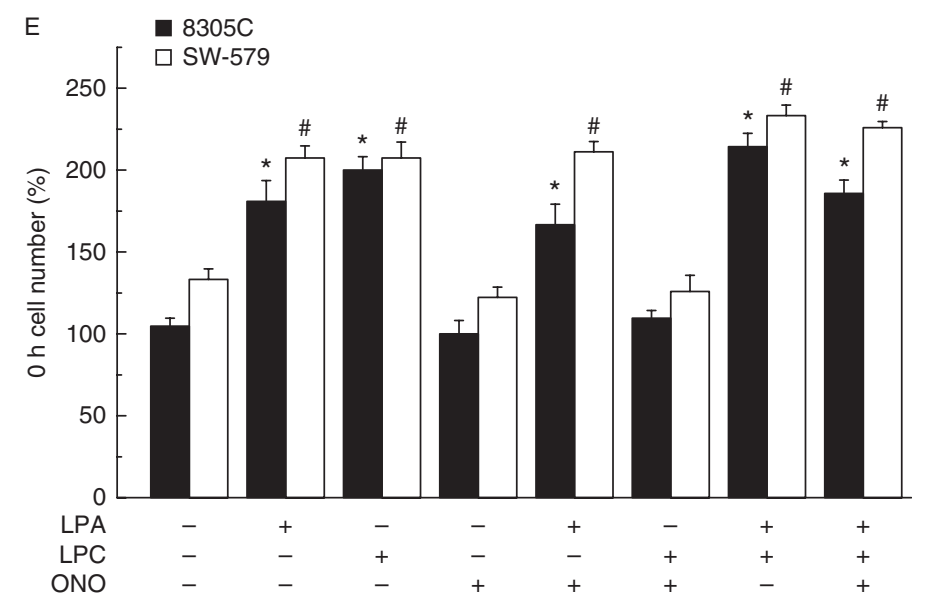

\section{Figure 6}

LPA increases the growth rate of thyroid cancer cells, and autotaxin inhibition blocks LPC-mediated cell growth. $8305 \mathrm{C}$ and SW-579 cells were grown in serum-free medium supplemented with $1 \%$ bovine serum albumin for $36 \mathrm{~h}$ and treated with or without $5 \mu \mathrm{M}$ LPA, $100 \mu \mathrm{M}$ LPC or $10 \mu \mathrm{M}$ of the autotaxin inhibitor ONO-8430506. (A, B, C and D) http://erc.endocrinology-journals.org DOI: $10.1530 /$ ERC-15-0045
(C) 2015 Society for Endocrinology Printed in Great Britain
Representative photographs of SW-579 cells after 36-h treatment. Scale bar $=1000 \mu \mathrm{m}$. (E) Counts of cells at the end of the 36-h treatment. Each sample represents three independent experiments, and results are expressed as means \pm S.E.M. ${ }^{*} P<0.05$ compared to no treatment for $8305 \mathrm{C}$ cells; ${ }^{\#} P<0.05$ compared to no treatment for SW-579 cells.

Published by Bioscientifica Ltd 
Autotaxin through LPA formation initiates a vicious cycle of inflammatory chemokine, cytokine and growth factor expression in human thyroid cancer cells

We next explored the mechanistic relationship between the elevated expression of autotaxin and inflammatory mediators using $8305 \mathrm{C}$ and SW-579 thyroid cancer cells. Incubation with LPA for $24 \mathrm{~h}$ increased the secretion of 16 chemokines, cytokines and growth factors with the exception of CCL2 and $1 \mathrm{~L} 1 \alpha$ in 8305C cells (Fig. 4, Supplementary Figure 4, see section on supplementary data given at the end of this article). These changes were accompanied by increased concentrations of the corresponding mRNAs (Supplementary Figure 5). Conversely, incubating the cancer cell lines with ten inflammatory chemokines and cytokines and the growth factors PDGF$\mathrm{AA}$ and BB markedly increased autotaxin mRNA expression and secretion (Fig. 5, Supplementary Figures 6 and 7). These results establish the importance of autotaxin in mediating a broad activation of the inflammatory cycle.

Thyroid cancer cell division was stimulated by LPC, and this depended on the catalytic activity of autotaxin since the autotaxin inhibitor ONO-8430506 completely blocked the effect (Fig. 6). As controls, we demonstrate that ONO-8430506 itself does not block LPA-induced cell division. Furthermore, the effects of LPC on cell division were additive with those of CCL2, IL1 $\beta$, IL6, IL8, GCSF, PDGF-AA, sCD40L and TNF $\alpha$. The autotaxin inhibitor ONO-8430506 blocked only the LPC-dependent component of this growth (Fig. 7, Supplementary Figure 8).

\section{Inhibition of autotaxin in mouse models of papillary thyroid cancer decreases tumour growth and abrogates the malignant inflammatory phenotype}

We hypothesized from the results described above that blocking LPA signalling would have two effects in thyroid tumour growth: it would attenuate both the direct effects of LPA and the indirect actions of the increased production of inflammatory mediators. This hypothesis was tested using a SCID mice model with the human thyroid cancer cell lines 8305C and SW-579, which are also highly tumorigenic. Daily dosing with $20 \mathrm{mg} / \mathrm{kg}$ of the autotaxin inhibitor ONO-8430506 at 7 days after establishing the tumours decreased tumour growth by nearly $60 \%$ (Fig. $8 \mathrm{~A}$ and $\mathrm{B})$. The inhibitor was well tolerated in mice, since no differences were seen in body weights between vehicle and ONO-8430506-treated groups (Supplementary Figure 9, see section on supplementary data given at the end of this article). This highly potent and selective autotaxin
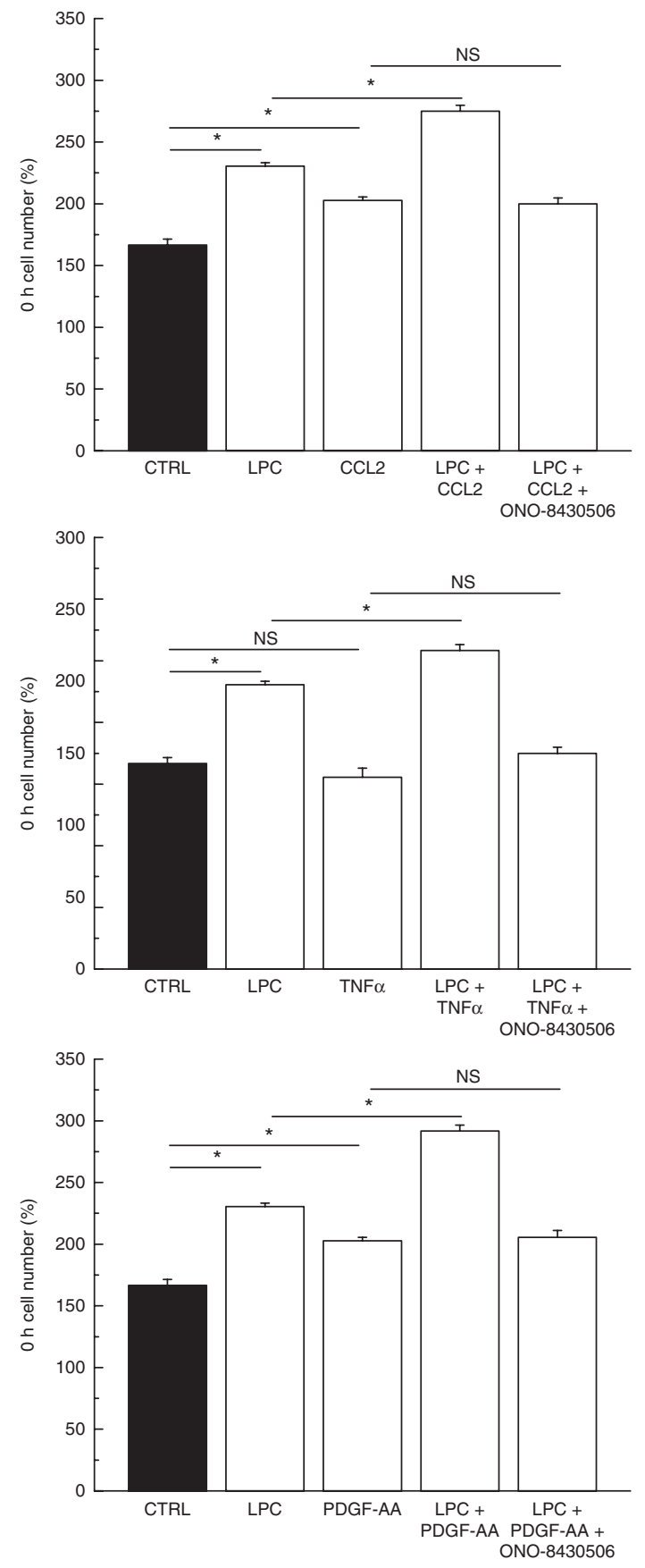

Figure 7

Effects of incubating SW- 579 thyroid cancer cells with LPC and chemokines, cytokines or growth factors. SW-579 cells were grown in serum-free medium supplemented with $1 \%$ bovine serum albumin for $36 \mathrm{~h}$ and treated with or without $100 \mu \mathrm{M}$ LPC, $10 \mathrm{ng} / \mathrm{ml} \mathrm{CCL2}$ or TNF $\alpha$, or $50 \mathrm{ng} / \mathrm{ml}$ PDGF-AA and $10 \mu \mathrm{M}$ of the autotaxin inhibitor ONO-8430506. Cells were then counted at the end of the 36-h treatment. ONO-8430506 blocked LPC-dependent cell growth. Each sample represents three independent experiments and results are expressed as means \pm s.E.M. CTRL, no treatment (control); ${ }^{*} P<0.05$; NS, not significant. Results for additional inflammatory mediators are presented in Supplementary Figure 8.

Published by Bioscientifica Ltd 

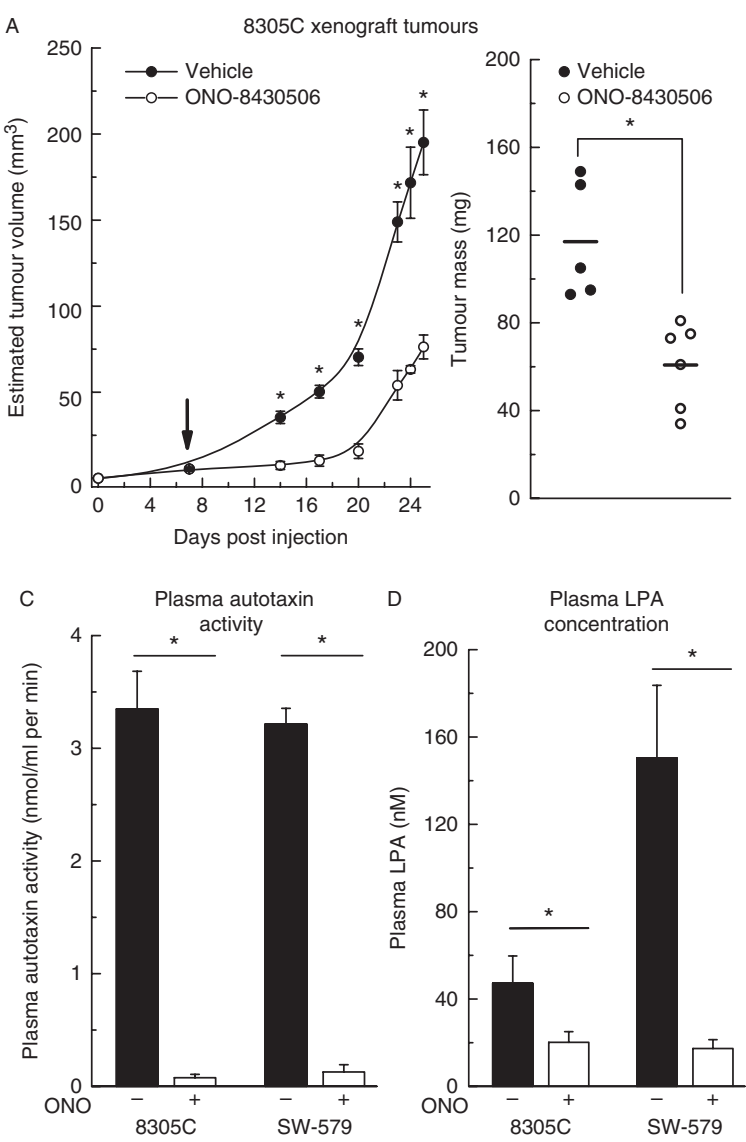

Figure 8

Autotaxin inhibition with ONO-8430506 slows the growth of xenograft thyroid tumours in SCID mice and reduces plasma autotaxin activity, LPA concentrations, tumour Ki67 and CD-31 staining. (A) Estimated tumour size and excised tumour mass from mice injected with $8305 \mathrm{C}$ cancer cells. $n=5-6$ per group. (B) Estimated tumour size and excised tumour mass from mice injected with SW-579 cancer cells. $n=6$ per group. In both experiments mice were gavaged daily with either vehicle or $20 \mathrm{mg} / \mathrm{kg}$

(ENPP2) inhibitor does not inhibit the activity of other ENPP family members nor does it affect ligand binding to 60 tested pharmacological targets (Saga et al. 2014). Effective autotaxin blockade with ONO-8430506 was demonstrated by the decreased plasma autotaxin activity (>90\%) and LPA concentrations (>70\%) (Fig. 8C and D). This was associated with a decreased mitotic rate and vascularity of the tumours as quantified by Ki67 (Fig. 8E, Supplementary Figure 10A) and CD-31 staining (Fig. 8F, Supplementary Figure 10B) respectively. Inhibition of autotaxin also decreased the concentrations of 14 inflammatory chemokines and cytokines within the tumours (Fig. 9A and B, Supplementary Figure 11). The effects on angiogenesis are compatible with the decreased PDGF-AA and VEGF concentrations caused by ONO-8430506 (Fig. 9C and D). Staining for the inhibited autotaxin in
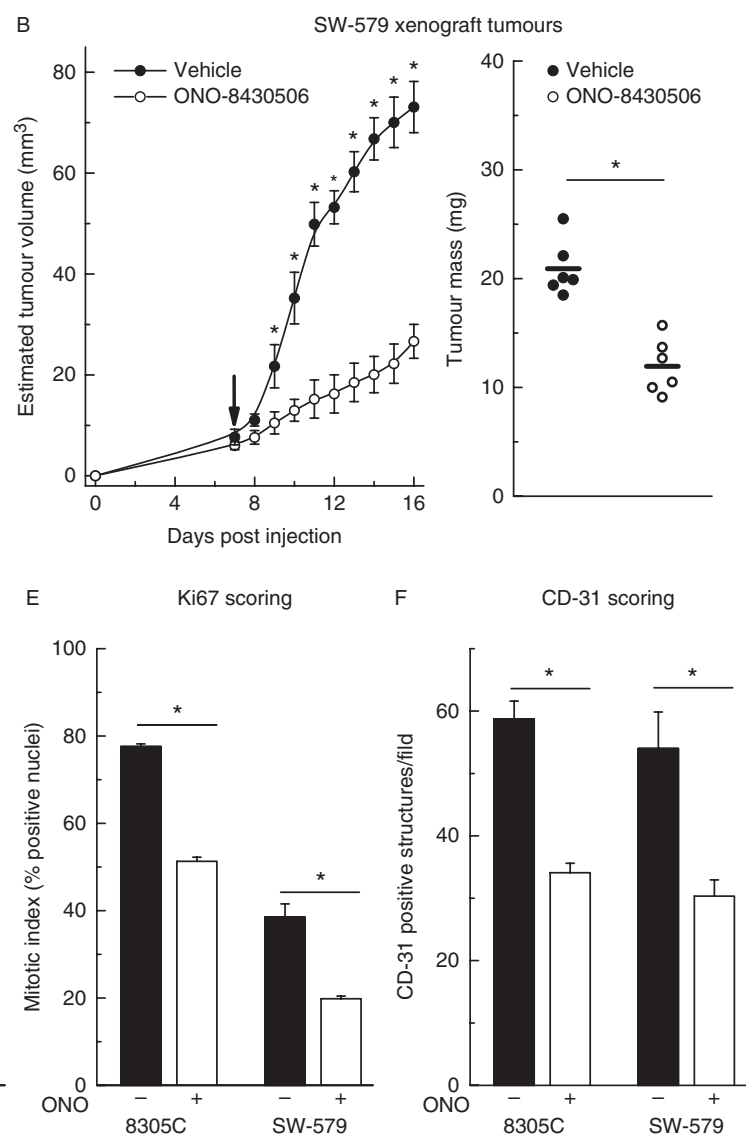

ONO-8430506 after 7 days of tumour growth (arrow). (C) Autotaxin activity and (D) LPA concentrations (sum of LPA species C16:0, C18:0, C18:1 and $\mathrm{C} 20: 4)$ in plasma collected $6 \mathrm{~h}$ after last treatment. $n=5-6$ per group. (E) Quantification of nuclear Ki67 staining and (F) quantification of CD-31 positive structures. $n=3-4$ per group. Representative photographs are in Supplementary Figure 10. All results are means \pm S.E.M. ${ }^{*} P<0.05$ compared to vehicle treatment.

tumours showed that it was confined to the cancer cells (Supplementary Figure 10C and D). Autotaxin inhibition did not alter the plasma concentrations of sphingosine-1phosphate and sphinganine-1-phosphate, sphingolipid analogs of LPA, which are not produced significantly by autotaxin (results not shown) (31-33).

\section{Discussion}

The present study provides a new paradigm for understanding the role of inflammation in papillary thyroid cancers. First, we show that autotaxin is a potent inflammatory mediator. High autotaxin expression and the resulting elevation in LPA concentrations are associated with an increased expression of inflammatory chemokines, cytokines and growth factors. This phenotype

Published by Bioscientifica Ltd 

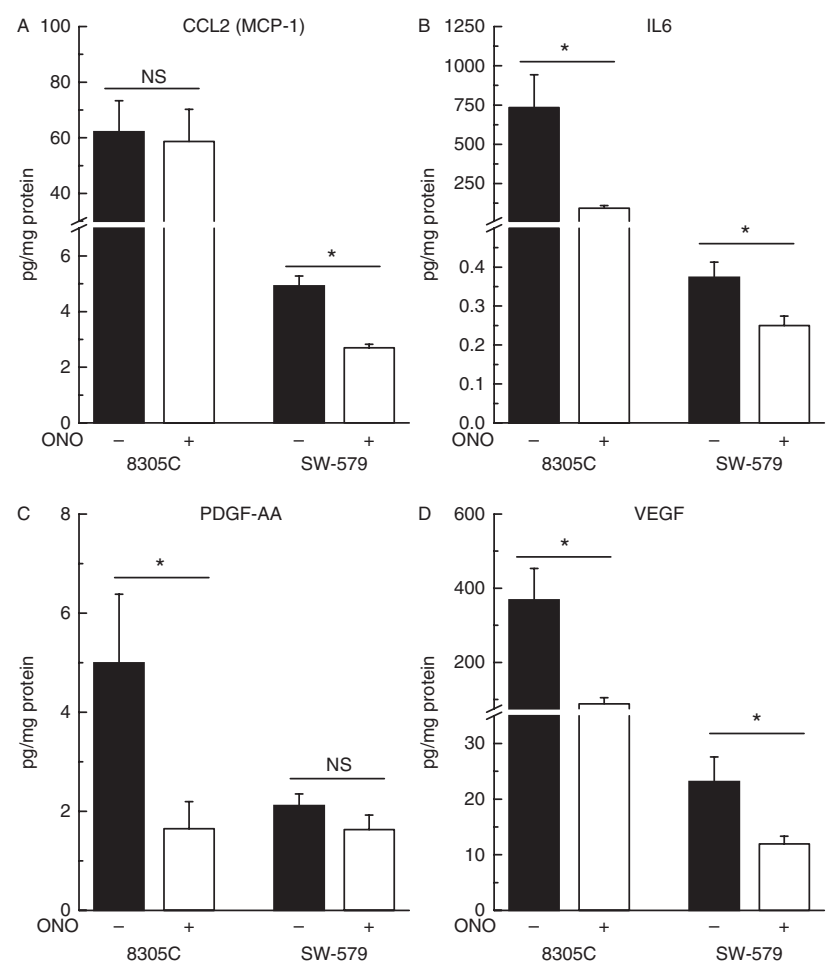

Figure 9

(A) Chemokines, (B) cytokines and (C-D) growth factors in $8305 \mathrm{C}$ and SW-579 xenograft thyroid tumours are significantly suppressed by ONO-8430506 treatment compared to vehicle treatment. Mice were treated daily with $20 \mathrm{mg} / \mathrm{kg}$ of the autotaxin inhibitor ONO-8430506, and vehicle mice were gavaged with water. Tumours were collected $6 \mathrm{~h}$ after last treatment. Multiplex measurement results are normalized to total protein content. Results are means \pm S.E.M. for $4-6$ mice per group. $* P<0.05$ compared to vehicle treatment; NS, not significant. Results for additional inflammatory mediators are presented in Supplementary Figure 11.

distinguishes malignant nodules and inflamed neoplasms from normal tissues and benign disease without leukocytic infiltration. Second, we document that the progressive inflammatory response persists in metastatic tissue where similar or even higher levels of inflammatory cytokines are observed compared to primary tumours. The inflammatory response leads to larger tumours with an increased mitotic rate and vascularity. This is similar to what is observed in aggressive disease where tumour size, mitotic rate and vascularity are linked with decreased survival (Chou et al. 2014). Third, treatment with ONO-8430506 decreases plasma LPA concentrations by $>70 \%$ as well as significantly decreasing the concentrations of several inflammatory modulators in our mouse models of thyroid cancer. These effects were accompanied by decreased tumour growth, which was associated with a decreased proliferative index and vascularity of these tumours.

The increased LPA concentrations in thyroid tumours relative to benign growths could result from increased glycerolipid synthesis associated with cancer cell growth. However, LPA from the biosynthetic pathway should not be released by cancer cells and thereby should not stimulate external LPA receptors. Furthermore, the concentration of C20:4-LPA, which is not produced in the de novo pathway, was also increased. Although polyunsaturated LPA species can be produced by phospholipase $A_{1}$ activities, autotaxin is responsible for the majority of LPA production (Benesch et al. 2014a). This conclusion is also supported by the observation that autotaxin inhibition decreases the concentrations of polyunsaturated LPA species in mouse breast tumours (Benesch et al. 2014b).

Despite the availability of autotaxin inhibitors over the last decade, most do not have good bioavailability (Federico et al. 2008, Albers \& Ovaa 2012, Barbayianni et al. 2013, 2015, Benesch et al. 2014a, 2015). By contrast, a daily dosage of mice with ONO-8430506 substantially decreased plasma autotaxin activity and LPA concentrations, and it produced a $50-60 \%$ decrease in breast tumour (Benesch et al. 2014b) and thyroid tumour growth. We propose that ONO-8430506, as a selective agent disrupting autotaxin activity, represents a new option for therapy for aggressive, metastatic papillary thyroid carcinoma. Autotaxin blockade also decreases the production of inflammatory mediators, which in other tumours promotes tumorigenesis, immune evasion and treatment resistance (Brindley et al. 2013, Tjomsland et al. 2013, Benesch et al. 2014a, Wang et al. 2014, Li et al. 2015).

Sustained inflammatory signalling and high autotaxin expression are correlated with the progression of hepatitis and inflammatory bowel diseases into cancer (Benesch et al. 2014a). In this study, autotaxin immunohistochemical staining was significantly elevated in benign adenomas with lymphocytic infiltration and Hashimoto's thyroiditis compared to those adenomas without infiltration. Progression of Hashimoto's thyroiditis to thyroid cancer has been proposed by several studies (Bozec et al. 2010, Azizi et al. 2014, Ehlers \& Schott 2014). Our results demonstrate that autotaxin inhibition decreases the inflammatory phenotype of thyroid tissue, possibly disrupting the potential for progression to malignant thyroid disease.

Our work with cultured thyroid cancer cells explains the connection between LPA signalling and inflammation in thyroid cancer that was inferred by previous studies (38-41). Autotaxin activity and LPA formation stimulated the production of inflammatory mediators, which resulted in a vicious cycle of more autotaxin secretion (Fig. 10). This inflammatory phenotype increased the division of thyroid cancer cells, and the component that depends

Published by Bioscientifica Ltd. 


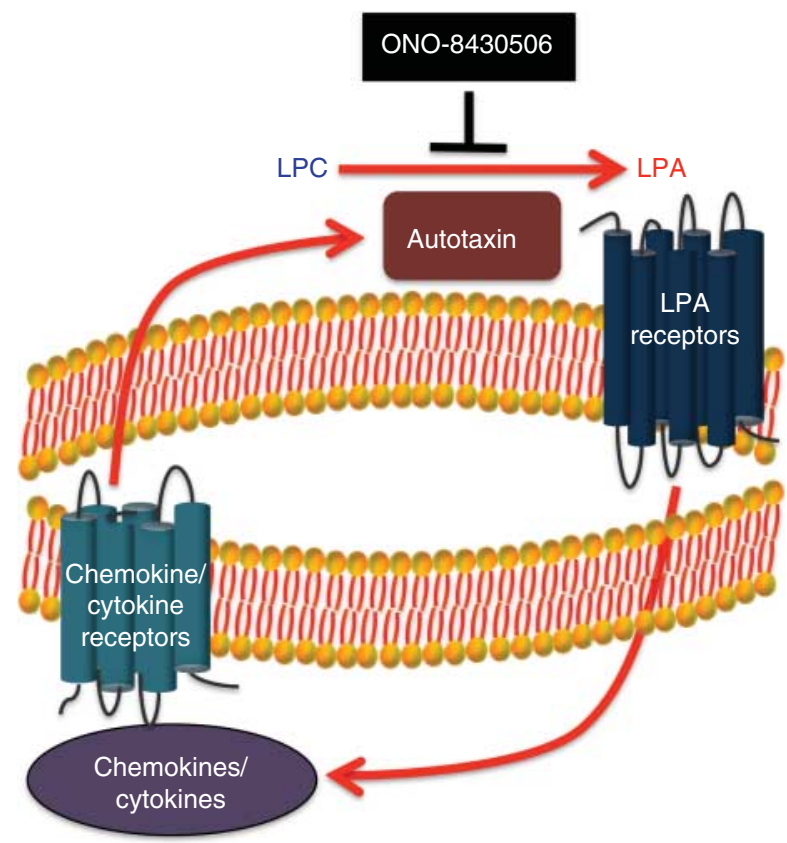

\section{Figure 10}

Model of the relationship between autotaxin/LPA and inflammatory chemokine and cytokine production and signalling in thyroid cancer cells. Autotaxin produces LPA by hydrolysing the choline headgroup from LPC. LPA signalling through its receptors leads to an increase in chemokine and cytokine production. These inflammatory mediators signal through their own receptors to further induce autotaxin production, establishing a vicious cycle that drives thyroid cancer progression. This cycle can be broken by inhibiting autotaxin catalytic activity with ONO-8430506, which in turn reduces both LPA and chemokine/cytokine concentrations and ultimately slows thyroid tumour growth. A full colour version of this figure is available at $\mathrm{http}: / / \mathrm{dx}$.doi.org/10.1530/ERC-15-0045.

directly on LPA formation was blocked by autotaxin inhibition. LPA also had an indirect effect on tumour growth by stimulating the production of inflammatory mediators, which also promotes growth. An interesting concept is that autotaxin may provide a singular focus for initiating the global inflammatory response in tumours, although the inflammatory mediators most important to particular cancer types may vary. For example, IL1 $\alpha$, IL6 and IL17 are involved in pancreatic, gastric and colorectal cancers respectively (Tjomsland et al. 2013, Wang et al. 2014, Li et al. 2015). In general, autotaxin/LPA signalling and the subsequently upregulated inflammatory programs drive tumour growth, immune evasion, metastasis, resistance to chemotherapy and decreased efficacy of radiotherapy in major cancers. These include melanomas, neuroblastomas, glioblastoma multiforme and breast, lung, colon, ovarian, renal cell and hepatic cancers (Gaetano et al. 2009, Samadi et al. 2009, Brindley et al. 2013, Hozumi et al. 2013, Benesch et al. 2014a,b, Venkatraman et al. 2015).
We used two SCID mouse models with human thyroid cancer cells to demonstrate the existence of the autotaxinLPA-inflammatory cycle in vivo. These mice have severe decreases in $\mathrm{T}$ and $\mathrm{B}$ lymphocyte expression, which prevents immune rejection of heterologous cancer cells. However, we could still determine the effects of the autotaxin inhibitor ONO-8430506 on the production of inflammatory mediators by the cancer cells themselves. ONO-8430506 had a long-acting effect in decreasing autotaxin activity and LPA production. As a result it effectively broke the inflammatory cycle by decreasing the concentrations of inflammatory cytokines in the thyroid tumours, resulting in decreased tumour growth. Our mouse models of thyroid cancer, which employ flank injections of cancer cells, do not lead to significant metastasis. However, inhibiting autotaxin activity and LPA signalling does decrease metastasis in other mouse models (Zhang et al. 2009, Schleicher et al. 2011, Benesch et al. 2014b, Venkatraman et al. 2015).

Tumours have been likened to 'wounds that do not heal' (Dvorak 1986, Schafer \& Werner 2008, Hanahan \& Weinberg 2011) and autotaxin is part of the defence mechanism used by the body to facilitate wound healing (Nakanaga et al. 2010, Okudaira et al. 2010). However, once wound repair is complete, autotaxin production levels should decrease. We recently demonstrated that LPA suppresses autotaxin production in a feedback regulatory loop. This feedback regulation is overcome by inflammatory mediators, such that high LPA and autotaxin levels can coexist in unresolved inflammation (Benesch et al. 2015).

In conclusion, we show that increased expression of autotaxin, LPA and inflammatory mediators is characteristic of malignant thyroid disease. Thus, autotaxin is an integral component of tumorigenesis in thyroid follicular cells. This includes driving tumour growth and promoting markers of more aggressive tumour phenotypes including proliferation, vascularity, metastasis, immune evasion and treatment resistance (Britschgi et al. 2012, Pylayeva-Gupta et al. 2012, Brindley et al. 2013, Chung et al. 2013, Benesch et al. 2014a). The inflammatory process mediated by autotaxin in thyroid cells is an autocrine cycle. This paradigm probably extends to other cancers such as glioblastomas and melanomas where autotaxin is secreted by the cancer cells (Kishi et al. 2006, Jankowski 2011). By contrast, breast cancer cells do not normally make significant quantities of autotaxin. Instead, the inflammatory milieu produced by the breast tumour stimulates autotaxin secretion by adjacent adipose tissue (Benesch et al. 2014b). In both scenarios, breaking the inflammatory

Published by Bioscientifica Ltd. 
cycle with a long-acting autotaxin inhibitor decreases tumour growth in mice. Therefore, regardless of where autotaxin is produced, autotaxin inhibition deprives cancer cells of LPA and the consequent secretion of a large variety of inflammatory chemokines and cytokines, which drive cancer progression. So far, no autotaxin inhibitor has been introduced into clinical practice. Our results support the use of autotaxin inhibition as a potentially new strategy for counteracting the autotaxinLPA-inflammatory axis, which drives the progression of thyroid and other cancers.

\section{Supplementary data}

This is linked to the online version of the paper at http://dx.doi.org/10.1530/ ERC-15-0045.

\section{Declaration of interest}

D $\mathrm{N}$ Brindley and T P W McMullen received consulting fees from Ono Pharmaceuticals Ltd, the developers of the autotaxin inhibitor ONO-8430506 used in this study. The other authors declare no conflicts of interest.

\section{Funding}

M G K Benesch received a Vanier Canada Graduate Scholarship (Government of Canada), a Canadian Institutes of Health Research (CIHR) MD/PhD Studentship, a MD/PhD Studentship from Alberta InnovatesHealth Solutions and a Killam Trust Award. X Tang held a research fellowship from the Canadian Breast Cancer Foundation (CBCF). The work was supported by grants from CBCF, CIHR with Alberta Cancer Foundation and Ono Pharmaceuticals Ltd.

\section{Author contribution statement}

M G K Benesch, D N Brindley and T P W McMullen conceived and designed the study. D N Brindley and T P W McMullen were responsible for financial support. M G K Benesch, Y M Ko, X Tang, J Dewald and A LopezCampistrous performed the experiments. $R$ Lai and T $P$ W McMullen provided study specimens and completed immunohistochemical scoring. Y Y Zhao and J M Curtis completed mass spectrometry measurements. M G K Benesch, R Lai, D N Brindley and T P W McMullen analysed and interpreted the results. D N Brindley and T P W McMullen supervised the project. M G K Benesch, D N Brindley and T P W McMullen wrote the manuscript, and all authors gave final approval to the manuscript.

\section{Acknowledgements}

We thank the University of Alberta Department of Oncology Cell Imaging Facility and Alberta Diabetes Institute HistoCore for their assistance.

\section{References}

Albers HM \& Ovaa H 2012 Chemical evolution of autotaxin inhibitors. Chemical Reviews 112 2593-2603. (doi:10.1021/cr2003213)
Allavena P, Garlanda C, Borrello MG, Sica A \& Mantovani A 2008 Pathways connecting inflammation and cancer. Current Opinion in Genetics \& Development 18 3-10. (doi:10.1016/j.gde.2008.01.003)

Altman MK, Gopal V, Jia W, Yu S, Hall H, Mills GB, McGinnis AC, Bartlett MG, Jiang G, Madan D et al. 2010 Targeting melanoma growth and viability reveals dualistic functionality of the phosphonothionate analogue of carba cyclic phosphatidic acid. Molecular Cancer 9 1476-4598. (doi:10.1186/1476-4598-9-140)

Ambesi-Impiombato FS, Parks LA \& Coon HG 1980 Culture of hormonedependent functional epithelial cells from rat thyroids. PNAS $\mathbf{7 7}$ 3455-3459. (doi:10.1073/pnas.77.6.3455)

Anderson RT, Linnehan JE, Tongbram V, Keating K \& Wirth LJ 2013 Clinical, safety, and economic evidence in radioactive iodine-refractory differentiated thyroid cancer: a systematic literature review. Thyroid 23 392-407. (doi:10.1089/thy.2012.0520)

Azizi G, Keller JM, Lewis M, Piper K, Puett D, Rivenbark KM \& Malchoff CD 2014 Association of Hashimoto's thyroiditis with thyroid cancer. Endocrine-Related Cancer 21 845-852. (doi:10.1530/ERC-14-0258)

Barbayianni E, Magrioti V, Moutevelis-Minakakis P \& Kokotos G 2013 Autotaxin inhibitors: a patent review. Expert Opinion on Therapeutic Patents 23 1123-1132. (doi:10.1517/13543776.2013.796364)

Barbayianni E, Kaffe E, Aidinis V \& Kokotos G 2015 Autotaxin, a secreted lysophospholipase D, as a promising therapeutic target in chronic inflammation and cancer. Progress in Lipid Research 58 76-96. (doi:10.1016/j.plipres.2015.02.001)

Barden CB, Shister KW, Zhu B, Guiter G, Greenblatt DY, Zeiger MA \& Fahey TJ III 2003 Classification of follicular thyroid tumors by molecular signature: results of gene profiling. Clinical Cancer Research 9 1792-1800.

Benesch MGK, Ko YM, McMullen TPW \& Brindley DN 2014a Autotaxin in the crosshairs: taking aim at cancer and other inflammatory conditions. FEBS Letters 588 2712-2727. (doi:10.1016/j.febslet. 2014.02.009)

Benesch MGK, Tang X, Maeda T, Ohhata A, Zhao YY, Kok BPC, Dewald J, Hitt M, Curtis JM, McMullen TPW et al. $2014 b$ Inhibition of autotaxin delays breast tumor growth and lung metastasis in mice. FASEB Journal 28 2655-2666. (doi:10.1096/fj.13-248641)

Benesch MGK, Zhao YY, Curtis JM, McMullen TPW \& Brindley DN 2015 Regulation of autotaxin expression by lysophosphatidate and sphingosine 1-phosphate. Journal of Lipid Research 56 1134-1144. (doi:10.1194/jlr.M057661)

Bhave SR, Dadey DY, Karvas RM, Ferraro DJ, Kotipatruni RP, Jaboin JJ, Hallahan AN, Dewees TA, Linkous AG, Hallahan DE et al. 2013 Autotaxin inhibition with PF-8380 enhances the radiosensitivity of human and murine glioblastoma cell lines. Frontiers in Oncology $\mathbf{3}$ 00236. (doi:10.3389/fonc.2013.00236)

Bozec A, Lassalle S, Hofman V, Ilie M, Santini J \& Hofman P 2010 The thyroid gland: a crossroad in inflammation-induced carcinoma? An ongoing debate with new therapeutic potential Current Medicinal Chemistry 17 3449-3461. (doi:10.2174/092986710792927804)

Brindley DN, Lin FT \& Tigyi GJ 2013 Role of the autotaxinlysophosphatidate axis in cancer resistance to chemotherapy and radiotherapy. Biochimica et Biophysica Acta 1831 74-85. (doi:10.1016/ j.bbalip.2012.08.015)

Britschgi A, Andraos R, Brinkhaus H, Klebba I, Romanet V, Muller U, Murakami M, Radimerski T \& Bentires-Alj M 2012 JAK2/STAT5 inhibition circumvents resistance to PI3K/mTOR blockade: a rationale for cotargeting these pathways in metastatic breast cancer. Cancer Cell 22 796-811. (doi:10.1016/j.ccr.2012.10.023)

Chopra M, Riedel SS, Biehl M, Krieger S, von Krosigk V, Bauerlein CA, Brede C, Jordan Garrote AL, Kraus S, Schafer V et al. 2013 Tumor necrosis factor receptor 2-dependent homeostasis of regulatory $\mathrm{T}$ cells as a player in TNF-induced experimental metastasis. Carcinogenesis 34 1296-1303. (doi:10.1093/carcin/bgt038)

Chou WC, Chen JS, Hung YS, Hsu JT, Chen TC, Sun CF, Lu CH \& Hwang TL 2014 Plasma chromogranin A levels predict survival and tumor 
response in patients with advanced gastroenteropancreatic neuroendocrine tumors. Anticancer Research 34 5661-5669.

Chung AS, Wu X, Zhuang G, Ngu H, Kasman I, Zhang J, Vernes JM, Jiang Z, Meng YG, Peale FV et al. 2013 An interleukin-17-mediated paracrine network promotes tumor resistance to anti-angiogenic therapy. Nature Medicine 19 1114-1123. (doi:10.1038/nm.3291)

Colotta F, Allavena P, Sica A, Garlanda C \& Mantovani A 2009 Cancerrelated inflammation, the seventh hallmark of cancer: links to genetic instability. Carcinogenesis 30 1073-1081. (doi:10.1093/carcin/bgp127)

Cunha LL, Marcello MA, Nonogaki S, Morari EC, Soares FA, Vassallo J \& Ward LS 2014a CD8 + tumour-infiltrating lymphocytes and COX2 expression may predict relapse in differentiated thyroid cancer. Clinical Endocrinology. (doi:10.1111/cen.12586)

Cunha LL, Marcello MA \& Ward LS 2014b The role of the inflammatory microenvironment in thyroid carcinogenesis. Endocrine-Related Cancer 21 R85-R103. (doi:10.1530/ERC-13-0431)

Dvorak HF 1986 Tumors: wounds that do not heal. Similarities between tumor stroma generation and wound healing. New England Journal of Medicine 315 1650-1659. (doi:10.1056/NEJM198612253152606)

Ehlers M \& Schott M 2014 Hashimoto's thyroiditis and papillary thyroid cancer: are they immunologically linked? Trends in endocrinology and metabolism 25 656-664. (doi:10.1016/j.tem.2014.09.001)

Euer N, Schwirzke M, Evtimova V, Burtscher H, Jarsch M, Tarin D \& Weidle UH 2002 Identification of genes associated with metastasis of mammary carcinoma in metastatic versus non-metastatic cell lines. Anticancer Research 22 733-740.

Federico L, Pamuklar Z, Smyth SS \& Morris AJ 2008 Therapeutic potential of autotaxin/lysophospholipase d inhibitors. Current Drug Targets 9 698-708. (doi:10.2174/138945008785132439)

Gaetano CG, Samadi N, Tomsig JL, Macdonald TL, Lynch KR \& Brindley DN 2009 Inhibition of autotaxin production or activity blocks lysophosphatidylcholine-induced migration of human breast cancer and melanoma cells. Molecular Carcinogenesis 48 801-809. (doi:10.1002/mc.20524)

Germano G, Allavena P \& Mantovani A 2008 Cytokines as a key component of cancer-related inflammation. Cytokine 43 374-379. (doi:10.1016/j.cyto.2008.07.014)

Grivennikov SI 2013 Inflammation and colorectal cancer: colitis-associated neoplasia. Seminars in Immunopathology 35 229-244. (doi:10.1007/ s00281-012-0352-6)

Hanahan D \& Weinberg RA 2011 Hallmarks of cancer: the next generation. Cell 144 646-674. (doi:10.1016/j.cell.2011.02.013)

Hassan AM, Alm El-Din MA, Nagy H, Ghoneem N, El-Heniedy MA, Koteb N \& El-Gohary S 2013 Significance of autotaxin activity and overexpression in comparison to soluble intercellular adhesion molecule in thyroid cancer. International Journal of Biological Markers 28 84-91. (doi:10.5301/JBM.2013.10780)

Hozumi H, Hokari R, Kurihara C, Narimatsu K, Sato H, Sato S, Ueda T, Higashiyama M, Okada Y, Watanabe C et al. 2013 Involvement of autotaxin/lysophospholipase D expression in intestinal vessels in aggravation of intestinal damage through lymphocyte migration. Laboratory Investigation 93 508-519. (doi:10.1038/labinvest.2013.45)

Hughes DT, Laird AM, Miller BS, Gauger PG \& Doherty GM 2012 Reoperative lymph node dissection for recurrent papillary thyroid cancer and effect on serum thyroglobulin. Annals of Surgical Oncology 19 2951-2957. (doi:10.1245/s10434-012-2380-9)

Jankowski M 2011 Autotaxin: its role in biology of melanoma cells and as a pharmacological target. Enzyme Research 8 194857. (doi:10.4061/2011/ 194857)

Jonkers J \& Moolenaar WH 2009 Mammary tumorigenesis through LPA receptor signaling. Cancer Cell 15 457-459. (doi:10.1016/j.ccr.2009.05. 003)

Jung CK, Little MP, Lubin JH, Brenner AV, Wells SA Jr, Sigurdson AJ \& Nikiforov YE 2014 The increase in thyroid cancer incidence during the last four decades is accompanied by a high frequency of BRAF mutations and a sharp increase in RAS mutations. Journal of Clinical
Endocrinology and Metabolism 99 E276-E285. (doi:10.1210/jc.20132503)

Kehlen A, Englert N, Seifert A, Klonisch T, Dralle H, Langner J \& Hoang-Vu C 2004 Expression, regulation and function of autotaxin in thyroid carcinomas. Journal of Clinical Endocrinology 109 833-838. (doi:10.1002/ijc.20022)

Kishi Y, Okudaira S, Tanaka M, Hama K, Shida D, Kitayama J, Yamori T, Aoki J, Fujimaki T \& Arai H 2006 Autotaxin is overexpressed in glioblastoma multiforme and contributes to cell motility of glioblastoma by converting lysophosphatidylcholine to lysophosphatidic acid. Journal of Biological Chemistry 281 17492-17500. (doi:10.1074/jbc.M601803200)

Li J, Lan T, Zhang C, Zeng C, Hou J, Yang Z, Zhang M, Liu J \& Liu B 2015 Reciprocal activation between IL-6/STAT3 and NOX4/Akt signalings promotes proliferation and survival of non-small cell lung cancer cells. Oncotarget 6 1031-1048.

Mantovani A 2010 Molecular pathways linking inflammation and cancer. Current Molecular Medicine 10 369-373. (doi:10.2174/ 156652410791316968)

Marcello MA, Cunha LL, Batista FA \& Ward LS 2014 Obesity and thyroid cancer. Endocrine-Related Cancer 21 T255-T271. (doi:10.1530/ERC-140070)

Murata J, Lee HY, Clair T, Krutzsch HC, Arestad AA, Sobel ME, Liotta LA \& Stracke ML 1994 cDNA cloning of the human tumor motilitystimulating protein, autotaxin, reveals a homology with phosphodiesterases. Journal of Biological Chemistry 269 30479-30484.

Nakanaga K, Hama K \& Aoki J 2010 Autotaxin - an LPA producing enzyme with diverse functions. Journal of Biochemistry 148 13-24. (doi:10.1093/ $\mathrm{jb} / \mathrm{mvq052)}$

Nikitopoulou I, Oikonomou N, Karouzakis E, Sevastou I, NikolaidouKatsaridou N, Zhao Z, Mersinias V, Armaka M, Xu Y, Masu M et al. 2012 Autotaxin expression from synovial fibroblasts is essential for the pathogenesis of modeled arthritis. Journal of Experimental Medicine 209 925-933. (doi:10.1084/jem.20112012)

Oikonomou E \& Pintzas A 2013 The TRAIL of oncogenes to apoptosis. BioFactors 39 343-354. (doi:10.1002/biof.1112)

Okudaira S, Yukiura H \& Aoki J 2010 Biological roles of lysophosphatidic acid signaling through its production by autotaxin. Biochimie $\mathbf{9 2}$ 698-706. (doi:10.1016/j.biochi.2010.04.015)

Pellegriti G, Frasca F, Regalbuto C, Squatrito S \& Vigneri R 2013 Worldwide increasing incidence of thyroid cancer: update on epidemiology and risk factors. Journal of Cancer Epidemiology 2013 965212. (doi:10.1155/ 2013/965212)

Provatopoulou X, Georgiadou D, Sergentanis TN, Kalogera E, Spyridakis J, Gounaris A \& Zografos GN 2014 Interleukins as markers of inflammation in malignant and benign thyroid disease. Inflammation Research 63 667-674. (doi:10.1007/s00011-014-0739-z)

Pylayeva-Gupta Y, Lee KE, Hajdu CH, Miller G \& Bar-Sagi D 2012 Oncogenic Kras-induced GM-CSF production promotes the development of pancreatic neoplasia. Cancer Cell 21 836-847. (doi:10.1016/j.ccr.2012.04.024)

Rahib L, Smith BD, Aizenberg R, Rosenzweig AB, Fleshman JM \& Matrisian LM 2014 Projecting cancer incidence and deaths to 2030: the unexpected burden of thyroid. liver, and pancreas cancers in the United States. Cancer Research 74 2913-2921. (doi:10.1158/00085472.CAN-14-0155)

Saga H, Ohhata A, Hayashi A, Katoh M, Maeda T, Mizuno H, Takada Y, Komichi Y, Ota H, Matsumura N et al. 2014 A novel highly potent autotaxin/ENPP2 inhibitor produces prolonged decreases in plasma lysophosphatidic acid formation in vivo and regulates urethral tension. PLOS ONE 9 e93230. (doi:10.1371/journal.pone.0093230)

Samadi N, Gaetano C, Goping IS \& Brindley DN 2009 Autotaxin protects MCF-7 breast cancer and MDA-MB-435 melanoma cells against Taxol-induced apoptosis. Oncogene 28 1028-1039. (doi:10.1038/ onc.2008.442) 
Schafer M \& Werner S 2008 Cancer as an overhealing wound: an old hypothesis revisited. Nature Reviews. Molecular Cell Biology 9 628-638. (doi:10.1038/nrm2455)

Schleicher SM, Thotala DK, Linkous AG, Hu R, Leahy KM, Yazlovitskaya EM \& Hallahan DE 2011 Autotaxin and LPA receptors represent potential molecular targets for the radiosensitization of murine glioma through effects on tumor vasculature. PLOS ONE 6 e22182. (doi:10.1371/journal. pone.0022182)

Seifert A, Klonisch T, Wulfaenger J, Haag F, Dralle H, Langner J, Hoang-Vu C \& Kehlen A 2008 The cellular localization of autotaxin impacts on its biological functions in human thyroid carcinoma cells. Oncology Reports 19 1485-1491. (doi:10.3892/or.19.6.1485)

Tafani M, De Santis E, Coppola L, Perrone GA, Carnevale I, Russo A, Pucci B, Carpi A, Bizzarri M \& Russo MA 2014 Bridging hypoxia, inflammation and estrogen receptors in thyroid cancer progression. Biomedicine \& Pharmacotherapy 68 1-5. (doi:10.1016/j.biopha.2013.10.013)

Tjomsland V, Bojmar L, Sandstrom P, Bratthall C, Messmer D, Spangeus A $\&$ Larsson M 2013 IL-1 $\alpha$ expression in pancreatic ductal adenocarcinoma affects the tumor cell migration and is regulated by the p38MAPK signaling pathway. PLOS ONE 8 e70874. (doi:10.1371/journal.pone. 0070874)

Turner MD, Nedjai B, Hurst T \& Pennington DJ 2014 Cytokines and chemokines: at the crossroads of cell signalling and inflammatory disease. Biochimica et Biophysica Acta 1843 2563-2582. (doi:10.1016/j. bbamcr.2014.05.014)

Venkatraman G, Benesch MG, Tang X, Dewald J, McMullen TP \& Brindley DN 2015 Lysophosphatidate signaling stabilizes Nrf2 and increases the expression of genes involved in drug resistance and oxidative stress responses: implications for cancer treatment. FASEB Journal 29 772-785. (doi:10.1096/fj.14-262659)

Wang K, Kim MK, Di Caro G, Wong J, Shalapour S, Wan J, Zhang W, Zhong Z, Sanchez-Lopez E, Wu LW et al. 2014 Interleukin-17 receptor a signaling in transformed enterocytes promotes early colorectal tumorigenesis. Immunity 41 1052-1063. (doi:10.1016/j.immuni. 2014.11.009)

Ward LS 2014 Immune response in thyroid cancer: widening the boundaries. Scientifica 2014 125450. (doi:10.1155/2014/125450)

Wu JM, Xu Y, Skill NJ, Sheng H, Zhao Z, Yu M, Saxena R \& Maluccio MA 2010 Autotaxin expression and its connection with the TNF- $\alpha-N F-\kappa B$ axis in human hepatocellular carcinoma. Molecular Cancer 9 1476-4598. (doi:10.1186/1476-4598-9-71)

Xue Y, Lim S, Yang Y, Wang Z, Jensen LDE, Hedlund E-M, Andersson P, Sasahara M, Larsson O, Galter D et al. 2012 PDGF-BB modulates hematopoiesis and tumor angiogenesis by inducing erythropoietin production in stromal cells. Nature Medicine 18 100-110. (doi:10.1038/ $\mathrm{nm} .2575)$

Zhang H, Xu X, Gajewiak J, Tsukahara R, Fujiwara Y, Liu J, Fells JI, Perygin D, Parrill AL, Tigyi G et al. 2009 Dual activity lysophosphatidic acid receptor pan-antagonist/autotaxin inhibitor reduces breast cancer cell migration in vitro and causes tumor regression in vivo. Cancer Research 69 5441-5449. (doi:10.1158/0008-5472.CAN-09-0302)

Zhang J, Wang P, Dykstra M, Gelebart P, Williams D, Ingham R, Adewuyi EE, Lai R \& McMullen T 2012 Platelet-derived growth factor receptor- $\alpha$ promotes lymphatic metastases in papillary thyroid cancer. Journal of Pathology 228 241-250. (doi:10.1002/path.4069)

Received in final form 19 May 2015

Accepted 2 June 2015

Made available online as an Accepted Preprint

2 June 2015
(C) 2015 Society for Endocrinology Printed in Great Britain 